\title{
PEMBERIAN BISKUIT MAKANAN TAMBAHAN MENINGKATKAN BERAT BADAN ANAK SEKOLAH DASAR DI KOTA SIBOLGA
}

\author{
SUPPLEMENTARY FEEDING PROGRAM WITH BISCUIT IMPROVED BODY \\ WEIGHT FOR SCHOOL-AGE CHILDREN IN SIBOLGA CITY \\ Bibi Ahmad Chahyanto ${ }^{1}$, Ivonna Hasfika ${ }^{1}$, Khoirul Anwar ${ }^{2}$, Yayuk Susilo ${ }^{1}$ \\ ${ }^{1}$ Bidang Kesehatan Masyarakat, Dinas Kesehatan Kota Sibolga, Indonesia \\ ${ }^{2}$ Program Studi Gizi, Fakultas Teknologi Pangan dan Kesehatan, Universitas Sahid Jakarta, Indonesia \\ (email penulis korespondensi : bibiahmadchahyanto@gmail.com)
}

Info Artikel: Diterima: 02 April $2020 \quad$ Revisi: 25 Mei $2020 \quad$ Disetujui: 20 Juni 2020

\begin{abstract}
ABSTRAK
Latar Belakang: Program Pemberian Makanan Tambahan dalam bentuk biskuit (BMT) merupakan salah satu upaya yang dilakukan untuk mengatasi masalah gizi kurang pada anak usia sekolah di Indonesia. Penelitian ini bertujuan untuk menganalisis perubahan berat badan anak sekolah setelah pelaksanaan program BMT di Kota Sibolga.

Metode: Penelitian menggunakan desain eksperimental semu dengan rancangan one group pretest-posttest dengan teknik pengambilan sampel yang digunakan adalah total populasi. Total responden sebanyak 203 orang dari penggabungan data hasil 2 kali program BMT pada tahun 2017 (Oktober - November) di SD Negeri 081228, 084082, dan 084083 (139 responden) dan tahun 2018 (Maret - April) di SD Negeri 081226 dan 081235 (64 responden). BMT terstandar sesuai acuan Peraturan Menteri Kesehatan Nomor 51 Tahun 2016 yang diberikan kepada responden sebanyak 1 bungkus (10 keping) per hari selama maksimal 36 hari.

Hasil: Hari Makan Anak (HMA) dalam studi ini berkisar antara 24 - 36 hari dengan rata-rata sebesar $32,50 \pm 2,73$ hari. Penelitian ini membuktikan bahwa terdapat hubungan yang signifikan $(p<0,05)$ antara umur dengan jumlah HMA, namun tidak terdapat hubungan yang signifikan $(p>0,05)$ antara jenis kelamin dengan jumlah HMA. Terjadi peningkatan rata-rata nilai $z$-score indeks IMT/U dan Berat Badan secara signifikan setelah intervensi BMT $(\mathrm{p}<0,05)$.

Kesimpulan: Pemberian BMT mempengaruhi peningkatan Berat Badan anak sekolah dasar di Kota Sibolga. Variabel yang mempengaruhi peningkatan Berat Badan adalah umur dan jumlah HMA.
\end{abstract}

Kata Kunci: Anak, berat badan, biskuit, kurang gizi, sekolah dasar

\begin{abstract}
Background: Supplementary Feeding Program in the form of biscuits (BMT) is one of the efforts made to address the problem of malnutrition in school-age children in Indonesia. This study aims to analyze changes in the weight of school children after the implementation of the BMT program in Sibolga City.

Methods: The study used quasi-experimental design with one group pretest-posttest design and the sampling technique used is total population. Total respondents were 203 people from the merging of the BMT program data results 2 times in 2017 (October - November) in Public Schools 081228, 084082, and 084083 (139 respondents) and 2018 (March-April) in Public Schools 081226 and 081235 (64 respondent). BMT is standardized according to the reference Minister of Health Regulation No. 51 of 2016 given to respondents as much as 1 pack (10 pieces) per day for a maximum of 36 days.

Results: the Children's Eating Day (HMA) in this study ranged from 24 - 36 days with an average of 32.50 \pm 2.73 days. This study proves that there is a significant relationship $(p<0.05)$ between age and the amount of HMA, but there is no significant relationship ( $p>0.05)$ between sex and the number of HMA. There was a significant increase in the mean z-score of the BMI / U index and Body Weight after BMT intervention $(p<0.05)$.

Conclusion: Supplementary BMT feeding program with biscuit improved body weight for school-age children in Sibolga City. Variables was a significant improved body weight are age and the amount of HMA.
\end{abstract}

Keywords: children, body weight, biscuits, malnutrition, primary school 


\section{PENDAHULUAN}

Anak Usia Sekolah (AUS) merupakan salah satu sasaran strategis pelaksanaan program gizi dan kesehatan. Hal ini karena usia sekolah termasuk ke dalam siklus daur kehidupan yang penting serta jumlahnya yang besar hingga $24 \%$ dari jumlah penduduk sehingga pertumbuhan dan perkembangannya perlu dipantau secara rutin. Selain itu, AUS relatif terorganisir dengan baik yaitu berada dalam satu wadah sekolah atau madrasah. ${ }^{1}$

Pertumbuhan dan perkembangan pada masa AUS, khususnya pada masa anak berusia 6-13 tahun menjadi dasar perkembangan anak pada masa selanjutnya. Pengawasan yang intensif terhadap tanda dan gejala penyimpangan tumbuh kembang yang mungkin dapat terjadi pada anak perlu mendapat perhatian khusus dari orangtua agar tidak mengganggu perkembangan anak kedepannya. ${ }^{2}$ Pertumbuhan dan perkembangan AUS tidak terlepas dari asupan gizi yang cukup dan seimbang. Namun pada kenyataannya, masalah gizi pada AUS khususnya anak Sekolah Dasar (SD) masih relatif tinggi.

Hasil Riset Kesehatan Dasar (Riskesdas) tahun 2018 menunjukkan bahwa prevalensi masalah gizi kekurusan (kurus dan sangat kurus) pada anak usia 5 - 12 tahun di Indonesia sebesar 9,2\%. Prevalensi kekurusan pada anak usia 5 - 12 tahun di Provinsi Sumatera Utara berada di bawah angka nasional yaitu sebesar $7,7 \% .^{3}$ Kota Sibolga merupakan kota kecil di

\section{METODE}

Penelitian ini menggunakan data sekunder dari hasil pelaksanaan Program Pemberian Biskuit Makanan Tambahan bagi Anak Sekolah (BMT-AS) SD di Kota Sibolga Tahun 2017 dan 2018. Desain studi yang digunakan adalah eksperimental semu dengan rancangan one group pretest-posttest. Program pemberian BMT-AS ini dilakukan pada bulan Oktober - November 2017 di tiga sekolah yaitu SD Negeri 081228, SD Negeri 084082, dan SD Negeri 084083 Kota Sibolga, dan pada bulan Maret - April 2018 di dua SD yaitu SD Negeri 081226 dan SD Negeri 081235.

Populasi dalam penelitian ini adalah seluruh siswa kelas 1 SD di 5 lokasi program sebanyak 220 siswa (2017) dan 79 siswa (2018). Teknik pengambilan sampel dalam
Provinsi Sumatera Utara yang terletak di wilayah pesisir Pantai Barat Pulau Sumatera. Penilaian status gizi dari hasil penjaringan peserta didik baru di salah satu kecamatan yang ada di Kota Sibolga (Kecamatan Sibolga Sambas) menunjukkan bahwa prevalensi kekurusan pada peserta didik baru Sekolah Dasar tahun ajaran 2017/2018 sebesar $15,12 \%{ }^{4}$

Salah satu program gizi dari pemerintah yang langsung ditujukan kepada AUS, khususnya anak SD adalah program pemberian Biskuit Makanan Tambahan Anak Sekolah (BMT-AS). Program ini ditujukan untuk meningkatkan asupan gizi anak selama di sekolah. ${ }^{(5)}$ Sama seperti kabupaten/kota lain yang ada di Provinsi Sumatera Utara, Pemerintah Kota Sibolga melalui Dinas Kesehatan juga melaksanakan program pemberian BMT-AS bagi anak SD. Keberhasilan program pemberian BMT-AS ini ditentukan oleh perubahan status gizi siswa setelah intervensi BMT-AS berakhir. Pemantauan status gizi secara antropometri pada siswa sebelum dan setelah pemberian BMT-AS di sekolah perlu dilakukan sebagai parameter perubahan dan indikator keberhasilan intervensi. Oleh karena itu, penelitian ini bertujuan untuk menganalisis perubahan berat badan anak sekolah setelah pelaksanaan program BMT-AS di Kota Sibolga.

penelitian ini adalah total populasi dengan kriteria inklusi data sampel adalah bersedia mengikuti seluruh rangkaian kegiatan penelitian yang dibuktikan dengan penandatanganan persetujuan menjadi responden setelah penjelasan (informed consent), siswa hadir pada saat proses pengumpulan data serta intervensi yang dilakukan sehingga memiliki kelengkapan data minimal Berat Badan (BB) sebelum dan setelah intervensi dilakukan, Tinggi Badan (TB), jenis kelamin, umur, dan jumlah Hari Makan Anak (HMA). Jumlah siswa yang memiliki data lengkap serta dapat diolah lebih lanjut dan menjadi sampel dalam studi ini sebanyak 139 siswa (2017) dan 64 siswa (2018) sehingga total sampel terolah sebanyak 
203 siswa. Kriteria eksklusi dari data sampel yang tidak dapat diolah adalah : 1) Data pengukuran BB sebelum intervensi tidak ada (siswa tidak hadir); 2) Data umur siswa tidak diketahui. Diagram alir pemilihan sampel pengolahan data dalam studi ini ditampilkan pada Gambar 1.

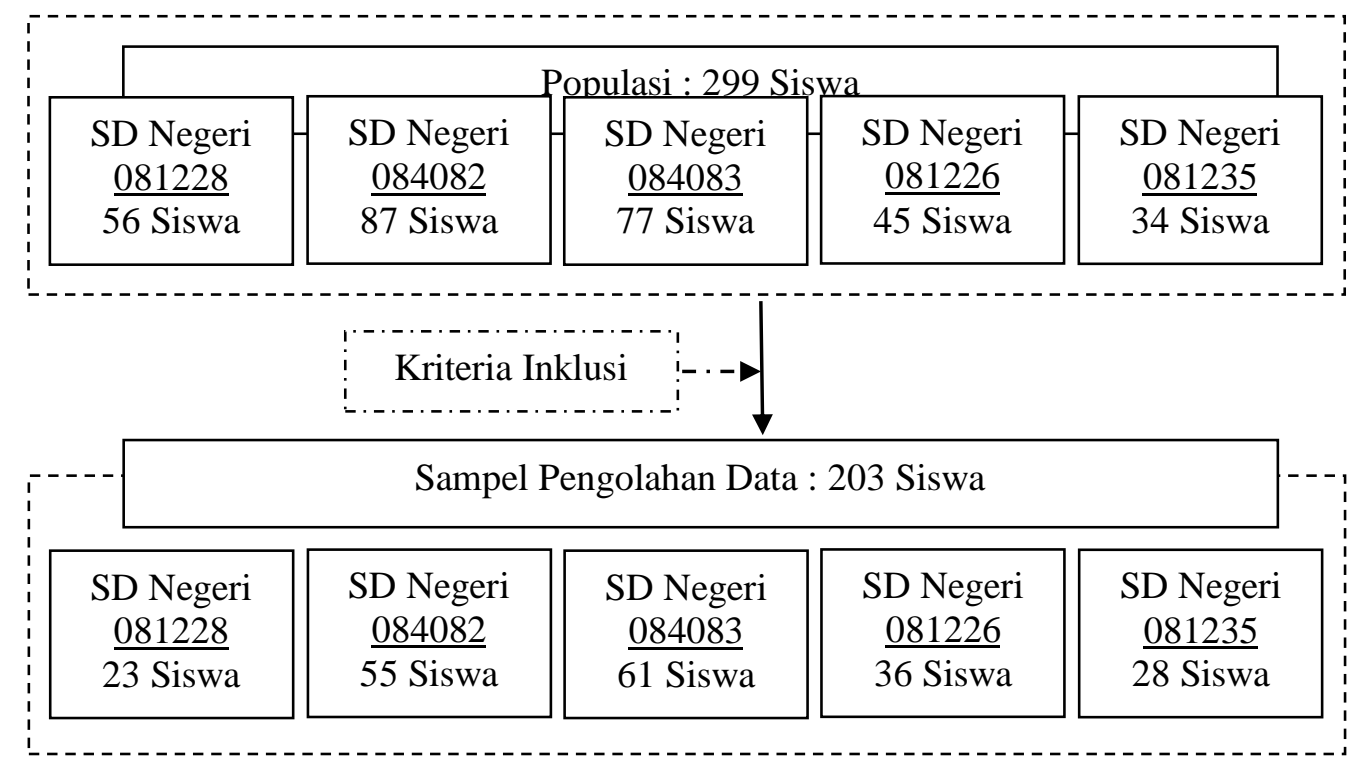

Gambar 1. Diagram Alir Pemilihan Sampel Pengolahan Data

Intervensi yang diberikan kepada siswa dalam program ini adalah pemberian Biskuit Makanan Tambahan atau disebut juga dengan Biskuit Makanan Tambahan Anak Sekolah (BMT-AS). BMT-AS adalah suplementasi gizi berupa makanan tambahan dalam bentuk biskuit dengan formulasi khusus dan difortifikasi dengan vitamin dan mineral yang diberikan kepada anak usia Sekolah Dasar/Madrasah Ibtidaiyah (SD/MI) untuk mencukupi kebutuhan gizi. BMT-AS diberikan sebanyak 1 bungkus yang berisi 10 keping (60 g) setiap harinya di sekolah. Pemberian BMTAS ini dipantau oleh guru kelas selama maksimal 36 hari sekolah (hari minggu dan hari libur nasional tidak dihitung). Biskuit diberikan kepada siswa sekitar 15 menit sebelum jam istirahat pertama (pukul 08.15 WIB) dan siswa diminta untuk menghabiskan seluruh biskuit yang diberikan. BMT-AS yang diberikan merupakan BMT-AS terstandar yang mengandung spesifikasi zat gizi khusus sesuai acuan Peraturan Menteri Kesehatan Nomor 51 Tahun 2016 tentang Standar Produk Suplementasi Gizi. Setiap sajian (10 keping)
BMT-AS mengandung $300 \mathrm{kkal}$ energi, $13 \mathrm{~g}$ lemak, $6 \mathrm{~g}$ protein, $40 \mathrm{~g}$ karbohidrat, 11 vitamin dan 7 mineral. ${ }^{(5)}$

Variabel yang diamati dalam penelitian ini adalah identitas siswa (nama, jenis kelamin, dan umur), Hari Makan Anak (HMA), Berat Badan (BB) siswa sebelum intervensi dan setelah periode intervensi BMT-AS, serta Tinggi Badan (TB) yang diukur sebelum intervensi. Variabel BB diukur menggunakan timbangan injak digital dengan ketelitian 0,1 $\mathrm{kg}$ dan TB diukur menggunakan mikrotoa dengan ketelitian $0,1 \mathrm{~cm}$. Pengukuran langsung dilakukan oleh tenaga kesehatan yang terlatih.

Umur siswa dikelompokkan menjadi kurang dari 6 tahun ( $<6$ tahun) dan lebih dari 6 tahun ( $\geq 6$ tahun) sesuai dengan syarat umur calon peserta didik baru kelas $1 \mathrm{SD} /$ sederajat. Hari Makan Anak (HMA) dalam studi ini adalah jumlah hari makan BMT-AS yang diberikan kepada siswa. Persentase nilai keberhasilan pemberian BMT-AS digunakan untuk menentukan kategori HMA. Rumus yang digunakan adalah: 


\author{
N HMA $=(\mathrm{SP} / \mathrm{SM}) \times 100 \%$ \\ Keterangan : \\ N HMA : persentase nilai keberhasilan pemberian BMT-AS \\ SP : Jumlah HMA yang didapat \\ SM : Jumlah HMA maksimal (36 hari)
}

Penilaian HMA dikategorikan ke dalam 4 kelompok, yaitu : 1) "Tidak baik" jika N HMA kurang dari 40\%; 2) "Kurang" jika N HMA antara $40-55 \%$; 3) "Cukup" jika N HMA antara 56 - 75\%; dan 4) "Baik" jika NHMA antara $76-100 \%{ }^{(6)}$

Variabel perubahan BB diperoleh dengan cara mengurangkan BB setelah dengan BB sebelum intervensi BMT-AS. Perubahan BB siswa dikategorikan ke dalam 3 kelompok, yaitu : 1) "Peningkatan" jika terjadi peningkatan BB setelah dari sebelum intervensi (perubahan BB bernilai positif); 2) "Tetap" jika BB setelah sama dengan sebelum intervensi (perubahan BB bernilai nol); dan 3) "Penurunan" jika terjadi penurunan BB setelah dari sebelum intervensi (perubahan BB bernilai negatif). Nilai $z$-score diperoleh dengan

\section{HASIL}

Siswa SD kelas 1 yang menjadi sampel dalam penelitian ini memiliki rentang umur mulai dari 5 tahun hingga 8 tahun. Rata-rata siswa berumur $6,44 \pm 0,59$ tahun. Tabel 1 menunjukkan bahwa proporsi responden berumur 6 tahun ke atas lebih banyak $(80,30 \%)$ dibandingkan dengan responden yang umurnya menggunakan aplikasi WHO AnthroPlus v1.0.4. ${ }^{(6)}$

Seluruh data selanjutnya disajikan dalam bentuk tabel distribusi frekuensi menggunakan program Microsoft excell 2010 dan dijelaskan secara deskriptif. Uji korelasi spearmen digunakan untuk menganalisis hubungan antara variabel umur serta jumlah HMA terhadap perubahan $\mathrm{BB}$ dan hubungan antara umur terhadap jumlah HMA. Uji chi square digunakan untuk menganalisis hubungan antara jenis kelamin dengan kategori perubahan BB. Uji t berpasangan (paired sample t-test) untuk menganalisis perubahan nilai z-score status gizi parameter IMT/U serta perubahan BB siswa sebelum dan setelah masa intervensi BMT. Seluruh hasil analisis statistik dinyatakan signifikan apabila nilai $\mathrm{p}<0,05$. kurang dari 6 tahun $(19,70 \%)$ pada saat program pemberian BMT-AS ini dilakukan.

Jumlah siswa berdasarkan jenis kelamin tidak terlalu berbeda antara laki-laki dengan perempuan (Tabel 1). Proporsi siswa berjenis kelamin perempuan $(50,25 \%)$ sedikit lebih banyak dibandingkan dengan responden berjenis kelamin laki-laki $(49,75 \%)$.

Tabel 1. Distribusi Karakteristik Responden $(n=203)$

\begin{tabular}{|c|c|c|}
\hline Karakteristik & Jumlah & Persentase (\%) \\
\hline \multicolumn{3}{|l|}{ Umur } \\
\hline$<6$ tahun & 40 & 19,70 \\
\hline$\geq 6$ tahun & 163 & 80,30 \\
\hline \multicolumn{3}{|l|}{ Jenis Kelamin } \\
\hline Laki-laki & 101 & 49,75 \\
\hline Perempuan & 102 & 50,25 \\
\hline \multicolumn{3}{|l|}{ Kategori HMA } \\
\hline Cukup & 7 & 3,45 \\
\hline Baik & 196 & 96,55 \\
\hline Kategori Perubahan BB & 44 & 21,67 \\
\hline \multicolumn{3}{|l|}{ Penurunan } \\
\hline Tetap & 18 & 8,87 \\
\hline Peningkatan & 141 & 69,46 \\
\hline TOTAL & 203 & 100 \\
\hline
\end{tabular}

Keterangan : HMA (Hari Makan Anak), BB (Berat Badan) 
Seluruh siswa yang menjadi sampel dalam penelitian ini diberikan intervensi yang sama yaitu berupa pemberian BMT-AS sebanyak 1 bungkus (10 keping) per hari selama 36 hari. Namun, pada kondisi yang sebenarnya masih ditemukan siswa yang tidak patuh mengonsumsi BMT-AS selama 36 hari masa intervensi sehingga memengaruhi jumlah HMA. Jumlah HMA terendah dalam penelitian ini adalah 24 hari dan tertinggi adalah 36 hari dengan rata-rata HMA sebesar 32,50 $\pm 2,73$ hari. Berdasarkan pengkategorian HMA, seluruh siswa dalam penelitian ini termasuk ke dalam kategori cukup dan baik. Proporsi siswa dengan kategori baik $(96,55 \%)$ jauh lebih tinggi dibandingkan dengan kategori cukup $(3,45 \%)$ (Tabel 1).

Tabel 1 juga menunjukkan sebaran siswa berdasarkan kategori perubahan BB. Sebagian besar siswa $(69,46 \%)$ mengalami peningkatan BB setelah intervensi pemberian BMT-AS dengan rata-rata peningkatan $\mathrm{BB}$ sebesar $0,72 \pm 0,74 \mathrm{~kg}$. Hanya sebagian kecil siswa saja yang mengalami penurunan BB $(21,67 \%)$ dan BB tetap $(8,87 \%)$.

Tabel 2. Jenis Uji dan Hasil Analisis Inferensia

\begin{tabular}{|c|c|c|}
\hline \multirow{2}{*}{ Variabel Independen } & \multicolumn{2}{|c|}{ Variabel Dependen } \\
\hline & Hari Makan Anak (HMA) & Perubahan BB \\
\hline Jenis Kelamin & $\begin{array}{c}\text { Fisher Exact Test } \\
\text { p-value }=0,721\end{array}$ & $\begin{array}{c}\text { Pearson Chi Square } \\
\text { p-value }=0,363\end{array}$ \\
\hline Umur & $\begin{array}{l}\text { Spearmen's Rho } \\
\text { p-value }=0,038\end{array}$ & $\begin{array}{l}\text { Spearmen's Rho } \\
\text { p-value }=0,000\end{array}$ \\
\hline Hari Makan Anak (HMA) & - & $\begin{array}{l}\text { Spearmen's Rho } \\
\text { p-value }=0,000\end{array}$ \\
\hline
\end{tabular}

Hasil uji statistik membuktikan bahwa umur memiliki hubungan signifikan $(p<0,05)$ dengan HMA siswa dalam pemberian BMTAS dengan $p$-value 0,038 , namun jenis kelamin tidak berhubungan signifikan $\quad(p>0,05)$ terhadap HMA siswa dengan p-value 0,721. Studi ini juga membuktikan bahwa tidak terdapat hubungan yang signifikan antara jenis kelamin siswa dengan perubahan $\mathrm{BB}(\mathrm{p}>0,05)$ dengan p-value 0,363 , namun terdapat hubungan yang signifikan antara umur dan HMA dengan perubahan $\mathrm{BB}(\mathrm{p}<0,05)$ (Tabel 2).

Tabel 3. Hasil Analisis Uji t Berpasangan

\begin{tabular}{|c|c|c|c|c|c|c|c|c|}
\hline \multirow{3}{*}{ Parameter } & \multicolumn{5}{|c|}{ Paired Differences } & \multirow{3}{*}{$t$} & \multirow{3}{*}{$d f$} & \multirow{3}{*}{$\begin{array}{l}\text { Sig. }(2- \\
\text { tailed })\end{array}$} \\
\hline & \multirow[t]{2}{*}{ Mean } & \multirow[t]{2}{*}{$\begin{array}{l}\text { Std. } \\
\text { Dev }\end{array}$} & \multirow[t]{2}{*}{$\begin{array}{c}\text { Std. } \\
\text { Error } \\
\text { Mean }\end{array}$} & \multicolumn{2}{|c|}{$\begin{array}{l}\text { 95\% Confidence } \\
\text { Interval of the } \\
\text { Difference } \\
\end{array}$} & & & \\
\hline & & & & Lower & Upper & & & \\
\hline $\begin{array}{l}\text { Nilai } z \text {-score IMT/U } \\
\text { Sebelum Pemberian } \\
\text { BMT - Nilai } z \text {-score } \\
\text { IMT/U Setelah } \\
\text { Pemberian BMT }\end{array}$ & $-0,198$ & 0,509 & 0,036 & $-0,269$ & $-0,128$ & $-5,538$ & 202 & 0,000 \\
\hline $\begin{array}{l}\text { BB Sebelum } \\
\text { Pemberian BMT - BB } \\
\text { Setelah Intervensi } \\
\text { BMT }\end{array}$ & $-0,389$ & 0,877 & 0,062 & $-0,508$ & $-0,265$ & $-6,282$ & 202 & 0,000 \\
\hline
\end{tabular}


Analisis statistik menggunakan uji $\mathrm{t}$ berpasangan (Tabel 3) membuktikan bahwa terdapat perbedaan yang signifikan $(\mathrm{p}<0,05)$ antara rata-rata $\mathrm{BB}$ siswa ( $p$-value $=0,000)$ dan

\section{PEMBAHASAN}

Pemberian suplementasi gizi merupakan upaya yang dilakukan untuk mencukupi kekurangan asupan gizi dari konsumsi makan harian yang dapat berakibat pada munculnya masalah kesehatan dan gizi pada kelompok rawan gizi. Salah satu program suplementasi yang dilaksanakan oleh pemerintah adalah Pemberian Makanan Tambahan pada Anak Sekolah, khususnya anak SD/MI. Program Pemberian Makanan Tambahan Anak Sekolah (PMT-AS) telah dimulai di Indonesia sejak tahun 1991. Berbagai konsep telah dikembangkan oleh Pemerintah Indonesia dalam program ini mulai dari pemanfaatan pangan lokal, susu, hingga biskuit sebagai bentuk PMT-AS. Penelitian ini khusus membahas dan mengevaluasi Program PMTAS dalam bentuk pemberian Biskuit Makanan Tambahan Anak Sekolah (BMT-AS). Pemberian makanan tambahan bagi anak usia sekolah dapat menjadi contoh kunci dalam peningkatan intervensi gizi, khususnya bagi anak dengan tingkat ekonomi rendah. ${ }^{5,7,8}$

Berat badan (BB) menjadi indikator antropometri penentu dalam penelitian ini karena mudah untuk diamati dan menggambarkan status gizi saat ini. Selain itu, BB merupakan ukuran tubuh yang menggambarkan massa tubuh termasuk cairan tubuh yang sensitif terhadap perubahan mendadak, seperti infeksi, kurang makan atau menurunnya nafsu makan. Sehingga tepat jika mengevaluasi pemberian BMT-AS dengan mengamati BB. ${ }^{9}$

Penelitian ini membuktikan bahwa pemberian BMT-AS yang mengandung spesifikasi zat gizi khusus sesuai acuan Peraturan Menteri Kesehatan Nomor 51 Tahun 2016 tentang Standar Produk Suplementasi Gizi, dapat meningkatkan rata-rata nilai $z$-score indeks IMT/U dan rata-rata BB siswa SD. Hasil ini sejalan dengan hasil penelitian sebelumnya yang membuktikan bahwa terdapat perubahan status gizi siswa $\mathrm{SD} /$ sederajat sebelum dan sesudah pemberian makanan tambahan anak sekolah (MT-AS). Namun jenis makanan, kandungan energi dan protein serta rata-rata nilai $z$-score parameter status gizi IMT/U ( $p$-value $=0,000)$ sebelum dengan setelah intervensi pemberian BMT-AS.

durasi pemberian MT-AS dalam dua penelitian terdahulu berbeda-beda. Penelitian sebelumnya mengintervensi MT-AS berupa makanan kudapan kudapan/ jajanan berbahan pangan lokal dan mengandung gizi setara $300 \mathrm{kkal}$ energi dan $5 \mathrm{~g}$ protein sebanyak tiga kali seminggu selama 9 bulan per tahun ajaran (108 kali/tahun). ${ }^{10}$

Angka kecukupan gizi yang dianjurkan bagi anak usia 7 - 9 tahun adalah $1.650 \mathrm{kkal}$ energi dan $40 \mathrm{~g}$ protein setiap harinya. ${ }^{11}$ Pemberian BMT-AS dalam penelitian ini menyumbangkan sekitar $18 \%$ energi dan $15 \%$ protein setiap harinya (kecuali hari minggu/libur). Sumbangan energi dan protein ini dapat menjadi salah satu faktor terjadinya peningkatan rata-rata $z$-score indeks IMT/U dan BB siswa SD. Asupan energi dan zat gizi dari makanan ke dalam tubuh, penyerapan dan penggunaan zat gizi, aktivitas yang dilakukan dan pola konsumsi sehari-hari merupakan faktor internal yang berperan terhadap status gizi. $^{12,13,14}$

Pemberian makanan tambahan di sekolah memang dirasakan pengaruhnya tidak terlalu besar, tetapi memberikan dampak positif bagi siswa, sekolah, dan lingkungan. Hal positif yang dirasakan seperti perubahan berat badan, kehadiran di sekolah, prestasi belajar di bidang matematika, aspek kognitif jangka pendek, dan juga perilaku anak sekolah. Ketahanan fisik murid yang lebih baik akan memberikan peluang menerima pelajaran lebih baik juga. ${ }^{14,15,16}$ Namun, rendahnya cakupan program PMT-AS saat ini di karena terbatasnya sumber daya yang dialokasikan untuk pembangunan manusia, keberagaman budaya masyarakat, serta tata kelola program yang kurang baik masih menjadi tantangan tersendiri di Indonesia. ${ }^{17}$

Penelitian ini juga membuktikan bahwa jumlah HMA dan umur mempengarui peningkatan BB. Hampir seluruh siswa SD dalam penelitian ini termasuk kategori HMA yang baik. Pemberian makanan tambahan tidak hanya sekedar untuk memenuhi rasa kenyang pada anak, tetapi perlu juga memperhatikan 
jumlah dan frekuensi pemberian termasuk HMA. Pemberian makanan tambahan yang tidak dilakukan dengan benar dapat menyebabkan anak tidak tercukupi kebutuhan gizinya bahkan dapat juga berakibat pada kelebihan gizi. ${ }^{(6)}$ Jumlah HMA yang dianjurkan Kemenkes dalam pemberian MT-AS pada sasaran dengan status gizi kurus adalah 90 hari, sedangkan kepada sasaran dengan status gizi normal adalah 30 hari (1 bulan). ${ }^{(5)}$

Umur merupakan salah satu determinan karakteristik individu yang mempengaruhi pemilihan makanan. Semakin tinggi umur maka kematangan anak akan semakin meningkat sehingga anak akan mulai menentukan pilihan makanannya sendiri. ${ }^{(18)}$ Sehingga, ada kemungkinan anak mengonsumsi makanan yang tinggi energi di luar BMT-AS yang diberikan yang dalam penelitian ini tidak dikoreksi melalui recall konsumsi makanan sehingga menjadi

\section{KESIMPULAN DAN SARAN}

Pemberian BMT-AS mempengaruhi peningkatan Berat Badan anak sekolah dasar di Kota Sibolga. Hasil penelitian ini dapat digunakan sebagai evaluasi dari program pemberian makanan tambahan dalam bentuk biskuit sesuai dengan aturan yang ada kepada anak sekolah. Studi ini juga menunjukkan manfaat yang baik dari program pemberian BMT-AS yaitu peningkatan BB. Namun, perlu diperhatikan juga pemberian BMT-AS pada siswa yang status gizi awalnya sudah berlebih

\section{UCAPAN TERIMA KASIH}

Terimakasih kepada Dinas Kesehatan Provinsi Sumatera Utara yang telah memberikan bantuan berupa Biskuit Makanan Tambahan bagi Anak Sekolah, serta Dinas Kesehatan Kota Sibolga yang telah memberikan izin dalam penggunaan data untuk penelitian ini. Terimakasih dan apresiasi yang

\section{DAFTAR PUSTAKA}

1. Kementerian Kesehatan RI. 2018. Petunjuk Teknis Penjaringan Kesehatan dan Pemeriksaan Berkala Anak Usia Sekolah dan Remaja. Jakarta: Kemenkes RI. keterbatasan dalam penelitian. Hal ini yang diduga mengakibatkan umur dapat mempengaruhi peningkatan BB.

Jenis kelamin tidak menjadi faktor yang berpengaruh terhadap peningkatan $\mathrm{BB}$ dalam penelitian ini. Hasil ini cukup berbeda dengan teori yang ada. Jenis kelamin merupakan salah satu faktor herediter yang mempengaruhi pertumbuhan anak. ${ }^{19,20}$ Perbedaan ini diduga karena Angka Kecukupan Gizi (AKG) yang dianjurkan pada umur 0 bulan sampai 9 tahun untuk laki-laki dan perempuan masih sama (tidak dipisahkan) sehingga persentase sumbangan energi dan protein dari BMT-AS yang diberikan terhadap zat gizi harian untuk kedua jenis kelamin tersebut akan sama juga Perbedaan hasil dengan teori dari penelitian lainnya dapat dipengaruhi oleh berbagai faktor seperti perbedaan metode dan alat ukur yang digunakan serta karakteristik responden penelitian. ${ }^{21}$

(overweight dan obes). Apabila pemberian BMT-AS dapat meningkatkan BB, maka dapat memperburuk kondisi siswa yang pada dasarnya kelebihan BB.

Disarankan kepada Pemerintah ataupun stakeholder untuk terus menjalankan program pemberian makanan tambahan serta memperhatikan status gizi awal anak sekolah sebelum dan sesudah pemberian makanan tambahan.

sebesar-besarnya disampaikan juga kepada Bapak H. M. Syarfi Huaturuk selaku Walikota Sibolga yang telah mendukung dan mengarahkan Program Pemberian Biskuit Makanan Tambahan Anak Sekolah (BMT-AS) di Kota Sibolga.

2. Cahyani FP, Furqon MT, Rahayudi B 2018. Identifikasi Penyimpangan Tumbuh Kembang Anak Dengan Algoritme Backpropagation, $J$ Pengembangan Teknologi Informasi dan Ilmu Komputer 
Universitas Brawijaya, 2(5):1778-86.

3. Kementerian Kesehatan RI, Badan Penelitian dan Pengembangan Kesehatan. 2018. Laporan Nasional RISKESDAS 2018. Jakarta: Badan Penelitian dan Pengembangan Kesehatan, Kemenkes RI.

4. Chahyanto BA, Aritonang ES, Laruska M. 2018. Status Gizi Anak Sekolah Dasar di Kecamatan Sibolga Sambas, Kota Sibolga, J Mitra Kesehatan, 1(2):59-67.

5. Kementerian Kesehatan RI. 2018. Petunjuk Teknis Pemberian Makanan Tambahan (Balita-Ibu Hamil-Anak Sekolah). Jakarta : Kemenkes RI.

6. Solo HT, Yudiernawati A, Neni M. 2017. Hubungan Antara Pemberian Makanan Tambahan Dengan Peningkatan Berat Badan pada Bayi 6-12 Bulan di Posyandu Wilayah Kerja Pos Kesehatan Desa (Poskesdes) Landungsari Kecamatan Dau Kabupaten Malang, Nurs News (Meriden), 2(2):709-18.

7. Gelli A, Aurino E, Folson G, Arhinful D, Adamba C, Osei-Akoto I, et al. 2019. A School Meals Program Implemented at Scale in Ghana Increases Height-for-Age During Midchildhood in Girls and in Children from Poor Households: A Cluster Randomized Trial, $J$ Nutr, 149(8):1434-42.

8. Lestari RT. 2011. Evaluasi Peran Program Pemberian Makanan Tambahan Anak Sekolah ( PMT-AS ) terhadap Status Gizi , Kadar Hemoglobin Dan Prestasi Belajar Siswa, Universitas Negeri Semarang, Semarang.

9. Supariasa IDN, Bakri B, Fajar I. 2016. Penilaian Status Gizi 2nd ed. Rezkina E, Agustin CA, editors. Jakarta: EGC.

10. Susilowati S. 2013. Perbedaan Status Gizi Anak Sekolah Dasar Sebelum dan Sesudah Mendapatkan Pemberian Makanan Tambahan (PMT) di SDN Plalan I Kota Surakarta, Universitas Muhammadiyah Surakarta, Surakarta.

11. Kementerian Kesehatan RI. 2019. Peraturan Menteri Kesehatan Nomor 28 Tahun 2019 tentang Angka Kecukupan Gizi yang Dianjurkan untuk Masyarakat Indonesia.

12. Dewi AM, Pradigdo SF, Rahfiluddin Z. 2017. Hubungan Asupan Energi dan Protein dengan Status Gizi Narapidana Umum (Studi di Lembaga
Pemasyarakatan Klas I Semarang Tahun 2016), J Kesehatan Masyarakat Universitas Diponegoro, 5(1):266-71.

13. Qamariyah B, Nindya TS. 2018. Hubungan Antara Asupan Energi, Zat Gizi Makro dan Total Energy Expenditure dengan Status Gizi Anak Sekolah Dasar, Amerta Nutr, 2(1):59-65.

14. Galloway R, Kristjansson E, Gelli A, Meir U, Espejo F, Bundy D. 2009. School Feeding: Outcomes and Costs, Food Nutr Bull, 30(2):171-82.

15. Kristjansson B, Petticrew M, Macdonald B, Krasevec J, Janzen L, Greenhalgh T, et al. 2007. School Feeding for Improving Physical and Psychosocial Health of Disadvantaged Students (Review), Cochrane Database Syst Rev, (1):1-139.

16. Rohima IE. 2016. Kajian Program Makanan Tambahan Untuk Anak Sekolah (PMT-AS) di Bandung, Infomatek, 18(1):17-26.

17. Sekiyama M, Kawakami T, Nurdiani R, Roosita K, Rimbawan R, Murayama N, et al. 2018. School Feeding Programs in Indonesia, Japanese $J$ Nutr Diet, 76(Supplement): S86-97.

18. Azrimaidaliza, Purnakarya I. Analisis Pemilihan Makanan pada Remaja di Kota Padang, Sumatera Barat, Kesmas: J Kesehatan Masyarakat Nasional 2011,6(1):17-22.

19. Sudiana IK, Yuni SA, Puteri ID. 2007. Peningkatan Berat badan pada Bayi (3-6 Bulan) melalui Infant Exercise, $J$ Ners, 2(2):1-5.

20. Yulni. 2013. Hubungan Asupan Zat Gizi Makro dengan Status Gizi pada Anak Sekolah Dasar di Wilayah Pesisir Kota Makassar, J MKMI, Desember:205-11.

21. Yusup F. 2018. Uji Validitas dan Reliabilitas Instrumen Penelitian Kuantitatif, $J$ Tarbiyah: $J$ Ilmu Kependidikan, 7(1):17-23. 